\title{
Utilization of Trade Preferences in Zambia: Firm Specific Issues
}

\author{
Mulenga Chonzi Mulenga ${ }^{1}$ \\ ${ }^{1}$ School of Social Sciences, Economics Department, Mulungushi University, Kabwe, Zambia \\ Correspondence: Mulenga Chonzi Mulenga, School of Social Sciences, Economics Department, Mulungushi \\ University, P.O. Box 80415, Kabwe, Zambia. Tel: 260-977-883-915. E-mail: mulengachonzi2002@ gmail.com
}

Received: September 12, 2020

Accepted: October 21, 2020

Online Published: November 5, 2020

doi:10.5539/ijef.v12n12p25

URL: https://doi.org/10.5539/ijef.v12n12p25

\begin{abstract}
Preferential agreements are intended to increase trade between countries involved. However, in reality, although the overarching purpose of these agreements in terms of market opening is often achieved, increases in trade is seldom realized. For countries like Zambia where data on trade via the preferential route are rarely captured, it is pertinent to analyze, from a firm's perspective, the utilization of the existing agreements. This study set out to analyze the extent of Zambia's utilization of trade preferences using both secondary and primary data sources. The secondary data establishes that despite these agreements having granted almost all Zambian exports duty-free and quota-free access, the country's utilization rates have been low. This result is affirmed by the exporters and further validated by the key informants as both surveys establish that Zambian firms have not utilized the trade preferences effectively. They have attributed the low utilization of these preferences to internal and external challenges. The internal challenges include: lack of production capacity, poor infrastructure, poor knowledge of markets, and high transport costs. Externally, the challenges include: difficulties in meeting sanitary and phyto-sanitary measures, costly rules of origin, technical barriers to trade and cumbersome paperwork requirements. The country therefore, needs to address these challenges if it is to utilize these agreements effectively.
\end{abstract}

Keywords: utilization rate, trade preference, firm, export, Zambia

\section{Introduction}

When countries enter into preferential agreements their objective is to reduce or remove tariffs and non-tariff barriers, thus allowing products to freely move across the borders of the partner countries. These agreements could either be reciprocal or non-reciprocal in nature. When developed countries unilaterally offer preferential trade concessions to developing countries, these are often referred as non-reciprocal trade agreements (North-South agreements) (Gil-Pareja, 2019). Whereas, when developing countries exchange trade preferences among themselves, these are called reciprocal trade agreement (South-South agreements) (Gil-Pareja, 2019). Ultimately, these preferential agreements are intended to increase the flow of trade between the countries involved and could also act as a trigger for investment flows between the partner countries. However, in reality, although the overarching purpose of these agreements in terms of market opening is often achieved, increases in the flows of trade are seldom realized. This has been attributed to the fact that, while these preferential agreements reduce or eliminate tariff barriers and non-tariff barriers, there remains a host of other barriers to trade that act as inhibitors to the expansion of trade among these countries. Some of these barriers include: failure by export firms to comply to requirements such as sanitary and phytosanitary (SPS) regulations, rules of origin (RoO), technical barriers to trade (TBT), besides insufficient trade facilitation (UNCTAD, 2018). Given this background and the fact that for countries like Zambia where data on trade via the preferential route are rarely captured, it is pertinent to analyze, from a firm's perspective, the extent of the usage of the existing preferences granted under these agreements. In order to make an assessment of trade flows through the preferential routes, a survey of the relevant stakeholders in the export business was conducted, which included export firms, business associations and government agencies. The study first examined the utilization of preferences at the country level through an extensive review of documents. However, due to lack of data particularly for reciprocal schemes within Africa, the analysis of this study was restricted to the non-reciprocal (North-South) agreements to which Zambia is party to. The study then analyzed the obstacles/challenges export firms encounter in utilizing these trade preferential schemes. Due to inadequate data on the utilization of preferences particularly for developing countries like Zambia, this study is relevant because it examines the 
actual beneficiaries of these preferential schemes so as to ascertain the extent of their usage and challenges they face in accessing them. This is meant to provide important insights to policy makers in future negotiations of these agreements.

Due to lack of data on the utilization of tariff preferences particularly in developing countries, few studies have been undertaken in this area in the developing world. The results from these few studies have varied, with some establishing that the utilization of the preferences was high while others found the utilization to be low. Among the studies that found high utilization of preference schemes were a study by Gil-Pareja et al. (2014) who found that trade preferences for developing countries had an export promoting effect - increasing exports by as much as 6 percent. In the same way, Thelle et al. (2015) looking exclusively at the European Union (EU) preference scheme, found that on average, trade preferences granted by EU countries significantly boosted developing countries' exports. Furthermore, Klasen et al. (2016) while examining the effectiveness of trade preferences for Least Developed Countries (LDCs) found that the system had worked for the LDCs and hence trade preferences could be considered effective for them. The Swedish National Board of Trade (NBT) (2018) which looked at the exporter and importer utilization of the EU's Free Trade Agreements (FTA) found that the EU's FTAs were in general utilized to a high degree and had the potential to increase even further. Similarly, Espitia et al. (2018) found that more than 80 percent of preferences granted by the EU were fully utilized in 2016 although the rate of utilization of preferences varied across countries. UNCTAD (2019) found that Africa's preference utilization rates of EUs preferential trade agreements between the period 2009-2016 were high (remained continuously above 90 per cent) although experiencing some fluctuations. Particularly, the study found that preference utilization rates for textiles and apparel, increased from 92.2 percent in 2011 to 94.9 percent in 2014 but thereafter, the rates decreased to 92.6 percent in 2016.

In contrast, Cirera and Alfieri (2012) in examining the impact of unilateral trade preferences in the EU on Mozambican exports found that export growth was weakly linked to the EU preference scheme as the main exported products showed lower than average use of the preference. Hakobyan (2015) also found similar results when he analyzed the developing countries utilization of the US-Generalized System of Preference (GSP) scheme. Further, Jones (2017) found that goods imported into the United States (US) under the GSP program were relatively static, averaging about $11 \%$ of all imports from GSP countries. The author attributed this relatively low utilization of the GSP program to many factors, among them GSP program uncertainty; product exclusion and long pauses between program authorization periods. In the same line, The WTO (2019) found that LDCs were often unable to fully utilize preferences even when their exports were subjected to simple origin requirements. The low utilization was attributed to certification of origin and/or transportation requirements. Furthermore, Akinmade et al. (2020) in assessing the United Kingdom's (UK) trade with developing countries under the GSP scheme found that beneficiaries of the UK-GSP scheme failed to utilize the preferences to the full extent and this was mainly due to low preference margins.

Unilateral trade preferences are created on the premise that they will aid developing countries expand their export earnings, stimulate industrialization and help them hasten economic growth. The effectiveness of these unilateral preference schemes can only be determined by gaining an understanding of the provisions offered under these schemes. The provisions differ from one scheme to the other and essentially this is likely to have an effect on the success or failure of the scheme. Table 1 give a comparison of the major provisions of the AGOA, EBA and the EU-GSP preference schemes. It is important to mention that, because there is no universal GSP programme for all countries, this study just includes the EU-GSP scheme as the EU remains one of Zambia's major export destinations. Moreover, it is claimed that the EU-GSP is the most widely used among the equivalent GSP systems (European Commission, 2005).

In comparing the systems, it would be very difficult to pinpoint which system is less or more restrictive and which system promotes or hampers export volumes more. From Table 1, it is however, quite obvious that the EBA scheme which is an extraction from the EU-GSP is less restrictive and therefore more attractive as it offers duty-free quota-free (DFQF) entry for a much larger range of products compared to the EU-GSP. Therefore, the comparison in this study is rather just between the AGOA and EBA schemes. Going by provision-to-provision comparisons, the preferences under the EBA seem to be more easily accessible compared to AGOA. For instance, access to the EBA scheme is automatic as countries need not apply for eligibility as opposed to AGOA, to which countries have to face administrative and other costs during the application process. In addition, EBA has DFQF access on all products with the exception of arms and ammunitions, while AGOA returns tariffs on a number of product lines. Further, EBA has no expiration date which makes it a more attractive export destination as it does not create any uncertainty, whereas AGOA preferences may be revoked at any time by the U.S. AGOA, however, seems to have an advantage over EBA and EU-GSP in terms of the rules of origin (RoO) particularly the 
"Special Rule" for beneficiary LDCs, which grants African producers of apparel articles preferential access of their products regardless of the use of third party fabric in the production of the products.

Table 1. Systems comparison in various unilateral preference schemes

\begin{tabular}{|c|c|c|c|}
\hline & \multicolumn{3}{|c|}{ Preference Scheme } \\
\hline & AGOA & EU-GSP & EBA \\
\hline $\begin{array}{l}\text { Terms of } \\
\text { Access } \\
\text { (Eligibility) }\end{array}$ & $\begin{array}{l}\text { - Restricted to SSA. } \\
\text { - Country has to apply for eligibility } \\
\text { applications are lengthy and costly } \\
\text { - Country should establish or be making } \\
\text { continual progress towards establishing: } \\
\text { > A market based economy. } \\
\text { > Rule of law and protecting workers } \\
\text { rights. } \\
\text { > Eliminating barrier to the US in terms } \\
\text { of trade and investment. } \\
>\text { Economic policies to reduce poverty } \\
\text { and tackling. } \\
\text { > Systems to combat corruption and } \\
\text { bribery. } \\
\text { > Protection of internationally } \\
\text { recognized worker rights. } \\
>\text { Country does not engage in activities } \\
\text { threatening U.S. national security or } \\
\text { foreign policy interests } \\
>\text { Does not engage in gross violations } \\
\text { of internationally recognized human } \\
\text { rights or aiding acts of international } \\
\text { terrorism. }\end{array}$ & $\begin{array}{l}\text { - Open for all developing countries } \\
\text { - Gives beneficiary countries either } \\
\text { reduced (preferential) or zero tariff } \\
\text { access to EU markets for their exports. } \\
\text { - Covers almost all products that have } \\
\text { tariffs levied on them. } \\
\text { - Least Developed Countries (LDCs) } \\
\text { receive duty-free access. }\end{array}$ & $\begin{array}{l}\text { - Open for any LDC } \\
\text { - Access to the scheme is automatic, } \\
\text { only exporters need to apply. }\end{array}$ \\
\hline $\begin{array}{c}\text { Type of } \\
\text { Access } \\
\text { (Product } \\
\text { Coverage) }\end{array}$ & $\begin{array}{l}\text { - Duty-free Quota-free access for over } \\
6,500 \text { tariff lines including all clothing } \\
\text { and certain textiles. } \\
\text { - Allows for special provisions for } \\
\text { certain apparel articles once eligibility is } \\
\text { proven. } \\
\text { - Duty-free treatment for any article } \\
\text { described in section 503(b)(1) (B) } \\
\text { through (G) that is the growth, product, } \\
\text { or manufacture of a beneficiary } \\
\text { sub-Saharan African country if it is } \\
\text { determined that it is not import sensitive. } \\
\text { - Need for documentation such as } \\
\text { production records, information relating } \\
\text { to the place of production, the number } \\
\text { and identification of the types of } \\
\text { machinery used in production, the } \\
\text { number of workers employed in } \\
\text { production, and certification from both } \\
\text { the manufacturer and the exporter. } \\
\text { - Maintained high tariffs on "import } \\
\text { sensitive" commodities such as sugar, } \\
\text { dairy and beef. }\end{array}$ & $\begin{array}{l}\bullet \text { Duty-free access for over 5,000 tariff } \\
\text { lines. } \\
\text { - Non-sensitive products enjoy } \\
\text { duty-free access, and represent about } \\
2400 \text { lines; } \\
\text { - Sensitive products (a mixture of } \\
\text { agricultural, textile, clothing, apparel, } \\
\text { carpets and footwear items) benefit } \\
\text { from tariff reductions (typically } 3.5 \\
\text { percentage points on ad valorem } \\
\text { duties) compared to the standard most } \\
\text { favoured nation tariff. Representing } \\
\text { over } 3000 \text { tariff lines. }\end{array}$ & $\begin{array}{l}\text { - Duty-free and quota-free access for } \\
\text { all products, except arms and } \\
\text { ammunitions. } \\
\text { - The Common Customs Tariff } \\
\text { duties on all products that are listed in } \\
\text { Chapters } 1 \text { to } 97 \text { of the Combined } \\
\text { Nomenclature, except those in } \\
\text { Chapter 93, originating in an EBA } \\
\text { beneficiary country shall be } \\
\text { suspended entirely. } \\
\text { - Tariffs on non-sensitive products } \\
\text { were suspended completely. } \\
\text { - Tariff reductions were undertaken } \\
\text { for "import sensitive" commodities, } \\
\text { for instance, reduction was set at } 30 \% \\
\text { for specific duties, and for ad valorem } \\
\text { duties, the reduction was set at } 3.5 \% \\
\text { - Tariffs on "import sensitive" } \\
\text { commodities such as fresh banana, } \\
\text { rice and sugar were to be removed in a } \\
\text { phase down approach until they } \\
\text { reached zero. (2006 for fresh bananas, } \\
2009 \text { for rice and sugar). }\end{array}$ \\
\hline
\end{tabular}


Preference $\bullet$ On average preference margins under

Margin AGOA are minimal, especially when compared to tariffs on products excluded from AGOA.

- For apparel products on average preference margins are high.

$\begin{array}{ll}\text { Rules of } & \text { - Product must be imported directly } \\ \text { Origin } & \text { from the AGOA-country into the United } \\ \text { States. } \\ \text { - Products must be the "growth product } \\ \text { or manufacture" of an } \\ \text { AGOA-beneficiary SSA which can be } \\ \text { met jointly by more than one } \\ \text { AGOA-beneficiary. }\end{array}$

- Product must be wholly produced in the beneficiary country, or that any imported materials that are used in the production of the export must be substantially transformed locally.

- Products may incorporate materials sourced from outside countries, provided that the sum of the direct cost or value of the materials produced plus the direct costs of processing undertaken in the AGOA-beneficiary country equals at least $35 \%$ of the production's appraised value.

- A total of $15 \%$ of the $35 \%$ may consist of US-originating parts and materials.

- Duty-free market access for apparel and textile articles if or when they are certified as complying with the "wearing apparel" provision.

- AGOA also includes a "Special Rule" for beneficiary countries that are LDCs which allows for apparel articles wholly assembled in the one or more LDC beneficiary to be given preferential treatment regardless of the country of origin of the fabric used to make the products.
- Preference margins differ across products but usually lower than under EBA.

- Generally, preference margins are equal to the MFN tariff as all exports apart from arms/ammunition and sensitive products are duty free.

Expiry - It has expiration dates. Current

Date expiration date is 2025.

(Stability) - Country eligibility is at the prerogative of the US president.

- Product imported under the EBA regime into the EU needs to have its origins in that country.

- Product must be "Wholly obtained" in a non-EU country: this refers to products that have no relation with any other country than the beneficiary country.

- Or product must be "sufficiently transformed" in a non-EU country country: referring to products which involve more than just the beneficiary country, for example using materials from another country.

- EBA uses three methods through which a product becomes sufficiently transformed.

$>\quad$ The change of tariff heading criterion: meaning that the finished product is classified under a different four-digit tariff heading than the non-originating materials are classified.

$>$ The ad valorem criterion: meaning that the customs value at the time of importation of non- originating materials used may not exceed a given percentage of the sum of the costs of the finished product.

$>\quad$ The specific process criterion: meaning that certain stages in a manufacturing process have to be carried out on any non- originating materials used.

- Has a direct transport rule ensures that the imported product was sent from the "originating country" without being manipulated in another country.

- Applies the Cumulation of origin rule which allows countries that have identical rules of origin and are in specific regional groups to use their combined resources to manufacture products and still be eligible for preferential tariff treatment.

- Product imported under the EBA regime into the EU needs to have its origins in that country.

- Product must be "Wholly obtained" in a non-EU country: this refers to products that have no relation with any other country than the beneficiary country.

- Or product must be "sufficiently transformed" in a non-EU country: referring to products which involve more than just the beneficiary country, for example using materials from another country.

- EBA uses three methods through which a product becomes sufficiently transformed.

$>$ The change of tariff heading criterion: meaning that the finished product is classified under a different four-digit tariff heading than the non-originating materials are classified.

$>$ The ad valorem criterion: meaning that the customs value at the time of importation of non-originating materials used may not exceed a given percentage of the sum of the costs of the finished product.

$>$ The specific process criterion: meaning that certain stages in a manufacturing process have to be carried out on any non-originating materials used.

- Has a direct transport rule ensures that the imported product was sent from the "originating country" without being manipulated in another country.

- Applies the Cumulation of origin rule which allows countries that have identical rules of origin and are in specific regional groups to use their combined resources to manufacture products and still be eligible for preferential tariff treatment.

- Has to be renewed every three years.

- Preferences can be temporarily withdrawn if:

- The scheme has no expiration date.

- Preferences can be withdrawn/suspended if: $>$ EU's financial interests are at 
- Monthly monitoring of imports of articles.

- Duty free treatment on an article may be withdrawn when such article from such country is being imported in such increased quantities as to cause serious damage, or threat thereof, to the domestic industry producing a like or directly competitive article. of principles laid down in the conventions listed in Part A of Annex VIII;

$>\quad$ export of goods made by prison labour;

$>$ serious shortcomings in customs controls on the export or transit of drugs, or failure to comply with international conventions on anti-terrorism and money laundering; $>$ serious and systematic unfair trading practices including those affecting the supply of raw materials, which have an adverse effect on the Union industry and which are prohibited or actionable under the WTO Agreements,

- serious and systematic infringement of the objectives adopted by Regional Fishery Organisations or any international arrangements to which the Union is a party concerning the conservation and management of fishery resources.

- Products in agricultural and fisheries sector may be subject to a special surveillance mechanism.

Source: US Trade and Development Act of 2000, EU Council Regulation 416/2001 (2001), Council Regulation 2501/2001 (2001), Council Regulation 1063/2010 (2010), Condon and Stern, http://agoa.info/about-agoa/rules-of-origin.html, http://agoa.info/about-agoa/apparel-rules-of-origin.html, European Commission

The EU market has traditionally been Zambia's main export destination. Between the periods 2011 and 2017, Zambia's exports were mainly destined to the EU's preferential schemes (see figure 1) with most of country's exports accessing the EU market under the EBA. However, despite being the most utilized preference scheme for Zambia's exports, the EBA scheme has experienced declining export volumes over the years as can be seen in figure 1. Between the period 2011 to 2017, the country's exports declined from $\$ 156$ million to $\$ 51$ million representing a 67 percent decline over the 6 -year period. This can be attributed to the global commodity price slumps experienced in that period as well as the declining demand for Zambia's major commodity export (copper). Exports to the other preference schemes remained very low but were stable during the same period.

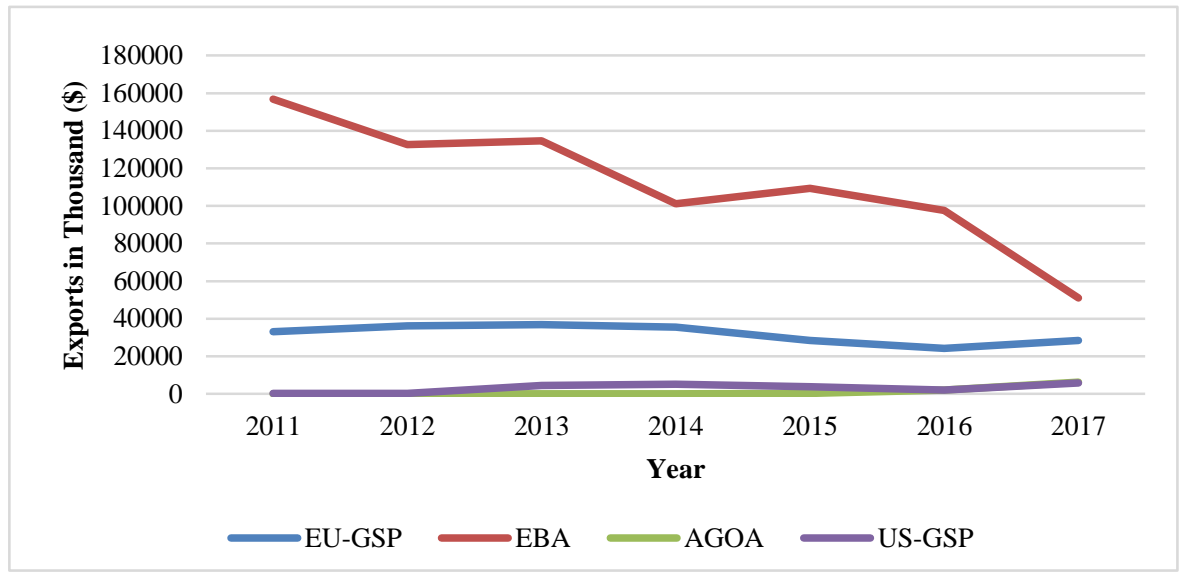

Figure 1. Zambia's export volumes in various unilateral preference schemes 


\section{Methods}

While developed countries have tried to help developing economies expand their exports and increase market access over a number of product lines, the question that arises is whether developing countries like Zambia are utilizing these preferences. The study uses both primary and secondary data sources. The secondary data looked at the country's exports (imports of the preferential partner) through various preferential schemes and from which we were able to calculate the utilization rates by dividing the value of preferential imports under a particular preferential scheme by the total value of imports that are eligible for preferential treatment. In order to identify the obstacles or challenges the country encounters in effectively utilizing the preferential schemes, this study conducted a primary survey of the major stakeholders particularly, the exporters and key informants such as business associations and government institutions involved in trade. Similar analysis has been undertaken in studies by Harris and Suominen (2009); Katsuhide and Urata (2010); OECD (2013) which focused on finding out firm-specific issues such as how they utilize the preferences and what determines and/or impedes their usage. However, no such studies have been undertaken in Africa and more specifically in Zambia as far as the researcher is aware.

The primary data was collected with the aid of structured questionnaires through interviews with exporters and key informants. The key informant interviews were conducted in order to validate the information given by the exporters. Two questionnaires were administered-one for exporters and the other for the trade associations/government agencies. For the exporters, the interviews were conducted with key personnel dealing in trade issues with an assurance that the information given would be treated with at-most confidentiality. The complete list of all exporters was obtained from the Zambia Revenue Authority and the study used purposive sampling to select the top 60 exporting firms. However, the study was only able to collect information from 38 firms as the other firms were either not willing to give out any information or the key personnel in charge was unavailable during the numerous attempts made to conduct the interview. This exercise was only undertaken to give us some insights as to whether firms were aware of the preference schemes, whether they utilized them, what determined and/or obstructed their use of the preference schemes, and what has been the impact. For the key informants, the study also used purposive sampling to collect information from the Ministry of Commerce Trade and Industry (MCTI), the Zambia Development Agency (ZDA), the Zambia Chamber of Commerce and Industry (ZACCI), the Zambia Export Growers Association (ZEGA) and the Zambia Association of Manufacturers (ZAM). The survey was undertaken in Lusaka, the country's capital as head offices of most firms as well as associations/government agencies are located there. The analysis was purely qualitative in nature due to the few number of respondents, and as such could not make any quantitative analysis. A thematic approach was employed to analyze the data. The survey addressed the following issues: the use of preference schemes; incentives/benefits/opportunities offered by the preference schemes; their impact in terms of opening new markets, profitability, innovation etc; the obstacles; and the role of government and trade associations in facilitating access to benefits of the agreements.

\section{Results}

Table 2 shows Zambia's utilization of some selected trade preferences. Generally, Zambia's utilization of trade preferences granted by developed countries has been quite low over the years in virtually all the preferences schemes analyzed. Comparatively, in 2017 Zambia utilized the EBA preference scheme more than any other preferential schemes. This was followed by AGOA $(\approx 10$ percent $)$ then the US-GSP for LDCs $(\approx 9$ percent $)$. The country's utilization of the tariff preferences offered by EU-GSP scheme was the least utilized $(\approx 8$ percent) in 2017 (see Table 2). The low utilization of these preferences point to the fact that there are other factors apart from tariffs that need to be addressed. The factors may be both internal and external. Internal factors may include: inadequate supply capacities, finance and information asymmetries while the external factors may include: excessive TBTs, RoO and SPS requirements.

Table 2. Zambia's utilization of selected preferential schemes, 2017 (Thousands of Dollars)

\begin{tabular}{lcccc}
\hline & AGOA & US-GSP for LDCs & EU-GSP & EU-LDC (EBA) \\
\hline Imports (\$) & 6,248 & 5,762 & 28,408 & 51,119 \\
Eligible Imports (\$) & 64,506 & 64,506 & 366,415 & 366,415 \\
Utilization Rate $\%)$ & 9.68 & 8.93 & 7.75 & 13.95 \\
\hline
\end{tabular}

Source: Authors compilation using data from http://tao.wto.org and www.dataweb.usitc.gov

Note. The imports given in the table are Zambia's exports recorded as imports by the unilateral trade partner. 
The questionnaire for exporters had a mixture of qualitative and quantitative questions and it was divided into two parts. The first part was about the general information of the firm and comprised some quantitative questions on the value of the firm's exports to which the respondents refused to disclose the information. The second part on the other hand addressed the free trade agreements and their impacts on the firm.

\section{Discussion}

Generally all the firms interviewed acknowledge their awareness of Zambia's trade agreements although their depth of knowledge varied - with some firms having detailed knowledge while others just had general knowledge. In terms of the extent of the utilization of preferences, most of the firms interviewed stated that they used preference schemes for their export products and they were beneficial, however, there was one firm that also utilized the preference scheme to obtain its imports of raw materials and in-turn received a duty drawback after producing and exporting the final product. The exporters also claimed that the preference schemes had played a great role in influencing their destination markets. In terms of exports, the U.S. and the EU markets were identified as the most important markets for most of the respondents while for imports the SADC market was identified as the most import source of imports of raw materials. One importer also stated that 'we have to import in order to be able to export, this increases production costs but the SADC certificates helps scrap of duty payments.' In addition, importing from SADC entails a reduction in cost due to proximity advantages. Most of the interviewed firms preferred to export to the EU market because they considered it more beneficial as the preference margins were quite high. Furthermore, the respondents claimed that the non-tariff measures under EU preferences schemes were more favorable than those under the U.S. and in particular AGOA. The majority of the respondents cited non-tariff barriers i.e. SPS issues for agricultural products, product specific standards and excessive paperwork as major obstacles to using the AGOA scheme. For instance, it was claimed by one agro exporter that for fresh produce for instance, the U.S. had imposed stringent phyto-sanitary measures that made it virtually impossible for the country to export. In particular the U.S. requested for a pest risk assessment (PRA) certificate which among other things proves that the agro exports are disease and pest free. To conduct these tests however, is very expensive as the country does not have the facilities or infrastructure nor laboratories to conduct such tests. The closest facility is in Botswana and this has proven to be very costly to exporters hence making their exports uncompetitive. The respondents also stated that these challenges are not only common to the U.S. preference schemes but also to other preference schemes though to a lesser degree. The challenges can be categorized as internal or external. Among the major internal challenges faced by exporters in utilizing the preference schemes are: lack of production capacity, poor infrastructure, and poor knowledge of markets and exchange rate instability. Externally, most of the exporters attributed the low utilization to difficulties in meeting technical standards in high export markets, costly RoO and SPS measures and cumbersome paperwork requirements.

Generally, there was a consensus among all the interviewed firms about the impact of the preference schemes on their firms. The results show that all firms responded to the affirmative of the impact of the preference schemes on their firms. When asked whether the trade agreements had permitted the opening of new market and stimulated trade for the firm, a majority of the respondents agreed that they had. For example, a few exporters claimed that they had started exporting their products to other preferential markets after realizing benefits from their traditional preferential markets. A number of them claimed that they had expanded their exports to the preferential markets in SADC and COMESA so as to benefit from the preferential treatment. Only two firms claimed that the trade agreements had generated opportunities for the development of new products and stimulated innovation in their firms. They claimed that the desire to come up with new products stemmed from the excessive competition faced in the export markets. 'Competition is stiff out there, to survive in the international market, you have to constantly innovate and come up with new and more attractive products, 'said one of the exporters. In terms of the contribution of preferential agreements to profitability, the number of employees and sales, all the firms claimed that the agreements had had a positive impact. However, what differed was the extent to which the agreements impacted on them with some firms agreeing that the trade agreements had contributed strongly while other merely agreeing yet others being indifferent. One firm for example claimed that it had hired and trained about 20,800 farmers across the country as suppliers of inputs for its exports to the U.S.

Finally, it was perceived by all exporters that the trade agreements had significantly contributed to the development of exports of the country in general. The respondents felt that both the Government and trade associations were vital in facilitating the utilization of preferences and therefore increase their benefits yet further from the agreements. The respondents however felt that while Government through its Ministry of Commerce Trade and Industry had played an active role in facilitating the use of benefits from the trade 
agreements, there was still need for more support from both the Government and trade associations, particularly in the following areas: market access services, access to finance, technology and product development services, supply of inputs, training and technical assistance, infrastructure-related and information services, and policy and advocacy. In reference to government support, one respondent praised the Zambian embassy in the U.S. for their important work in facilitating market access. 'Market issues are very vital and through Exhibitions at the embassy our products continue to be known' stated the exporter. The export firms therefore want embassies to take a lead in promoting their products through exhibitions as a way to market their products. The firms also think there is need for the government to come up with one stop shops where all the necessary documentations for exports into these preferential markets can be obtained under one roof if the country is to reap the benefits from the preferential schemes further.

In order to validate the findings from the survey on utilization of preferences by exporters, we simultaneously undertook another survey of key informants particularly Government institutions and trade associations. The survey interviewed five key informants - two government institutions and three trade associations (See Appendix).

There seems to be a general consensus among all the key informants concerning firms' utilization and the benefits they derive from preferential trade agreements. They seem to all agree that firms have underutilized the preferential trade agreements and that they have not benefited much from them. KI-1 attributed the low utilization to many factors, however what came out strongly was that the SPS measures are very stringent to the point that they have zero tolerance to pests and diseases. For instance, since the implementation of the AGOA initiative in 2000, only three products under fresh produce from Zambia qualify to be exported into the U.S. to date. These products are Snow Peas, baby Carrots and baby Corn. This should be a matter of concern to the country due to the fact that, it has been 19 years since implementation of the AGOA initiative and the country has not been able to expand its exports of fresh produce. Even more worrisome is the fact that the country is primarily a producer of fresh produce and the sector employs over half of the population and yet it has been unable to explore ways in order to expand its exports in the sector. This to a very large extent shows lack of commitment and failure by the exporters and government to address the internal and external challenges that the sector faces.

In terms of which preferential agreements was perceived to be more beneficial to the exporters, the majority of the respondents pointed to the COMESA agreement. The respondents felt that due to COMESA being a regional agreement, issues of costs associated with distance fall off, hence the country tends to benefit more. This also hold true for SADC, however, what makes COMESA more attractive are the more relaxed RoO compared to those in SADC. Furthermore, KI-2 stated that 'Regional markets particularly the COMESA market is very beneficial to the country and this has been due to the good infrastructure at the borders e.g. the one stop border concept which has greatly reduced the time spent at borders, hence facilitated more trade. 'It is a well-known fact that customs delays at the borders are a cost to businesses hence their reduction has led to more trade between Zambia and its regional partners thereby benefitting the country greatly. KI-2 however, perceived that SADC was more beneficial to Zambia as is evident from the large trade flows between Zambia and SADC. KI-2 attributed this to lower transport costs due to proximity, improved border infrastructure that reduces time spent at borders and less burdensome product specific standard requirements.

The results from the key informant survey also show that all the respondents perceived NTMs as being more decisive in determining the destination of the country's exports. With the tariff liberalization in the trade agreements, it is quite obvious that the only obstacles that remain to the country's utilization of trade preferences are NTMs and other domestic constraints. In much the same way as the firms, the key informants reported that SPS for agro produce were among the main challenges to exporters utilizing the preferences particularly in those agreements with developed countries. While the U.S. already has implemented very strict SPS measures, the EU is also in the process of implementing stricter SPS measures which come into effect on $14^{\text {th }}$ December 2019 . This is despite the fact that developed country agricultural commodities are already highly subsidized. This move will make it even more difficult for Zambian agro exports to penetrate these markets. Apart from SPS, other external constraints include: extensive documentation and lengthy procedures, TBTs and stringent RoO. Among the prevalent internal constraints are: inadequate infrastructure to support industries and exports, limited access to finance as a result of Government crowding-out private sector borrowing due to its excessive borrowing from the domestic market, high cost of borrowing and collateral requirements by lenders; policy inconsistencies; and high transport costs which may include port charges and cost of delays at borders. Zambia is faced with poor supporting industries e.g. financial, telecommunications, transport and energy which are key in the manufacturing process thereby hampering domestic output and external trade expansion. The country also lacks internationally accredited laboratories to conduct tests on products destined for export markets. KI-5 stated that the closest lab to conduct pest risk assessment for Zambian fresh produce to be accepted into the U.S. is in 
Botswana. This therefore is an additional cost to the exporters and make Zambian exports less competitive.

In terms of the impact of the preferential trade agreements, the respondents generally felt that there had been very little impact of the agreements on both the firms and the country as a whole. They however all perceived that the agreements had permitted the opening of new markets and had fostered Foreign Direct Investment (FDI) inflows. The Associations also seemed to agree that the government had made efforts to consult them regularly and include them in the trade negotiation process although they felt that the consultations were often conducted in a hurried manner. In terms of specific actions taken by the government to promote the use of the agreements by export firms, the government had given tax incentives on the importation of raw materials, duty drawbacks and manufacturing under bond. The government had also created a revolving fund with a very low interest in order to help exporters produce and export more to the international markets. "We have set out interventions to tackle bottlenecks related to market expansion, trade facilitation, production, access to finance and in more general terms, wealth and job creation, with the objective of enhancing the competitiveness of Zambia's exports at regional and multilateral levels"' stated KI-4. KI-3 on the other hand said that they helped exporters by providing technical and financial support for the development of export, market intelligence and other trade promoting activities. The key informants particularly the associations also felt that market intelligence was key in penetrating the preferential markets and as such there was need for the government conduct research and provide detailed information to the exporters about these preferential markets.

\section{Conclusion}

Generally, preference schemes are seen as an opportunity for developing countries to expand their export capacities by avoiding costs not compatible with their development needs. In addition, the preferential trade schemes are intended to encourage firms to be more competitive internationally, bolster economic growth, reduce unemployment, and help alleviate poverty. This study has found that Zambia's utilization of the preferences is quite low. However, due to the unavailability of data on reciprocal schemes in Africa, our analysis of Zambia's utilization of trade preferences was restricted to the reciprocal trade agreements granted by developed countries. Particularly, the analysis only covered the preference schemes granted by the EU and U.S., namely, the EU-GSP, the US-GSP and AGOA.

Our finding show that, despite these preference schemes having granted DFQF access to almost all of the Zambia's exports, the country has not benefited much from them. The country has performed dismally poor on many accounts. From the secondary data analysis, Zambia's utilization of preferences is quite low and to verify this, the study undertook a survey of exporters and key informants. The survey of exporters was undertaken with the aim of analyzing the extent of the use of the preference schemes and identifying the actual obstacles that prevented firms from using the preferential trade agreements. The survey of key informants on the other hand was undertaken to validate the findings from the survey of exporters. The results from both surveys seem to affirm that Zambia has not utilized the trade preferences effectively though they both claimed that preference schemes had played a great role in influencing destination markets of the country's exports. However, while the exporters felt that the U.S. and the EU markets were the most important markets for their exports and the SADC market for their imports, the key informants pointed to the COMESA agreement as being more beneficial to exporters. Most of the exporters preferred to export to the EU market because they perceived the preference margins to be higher. Furthermore, they claimed that the NTMs under the EU preference schemes were more favorable than those under the U.S. and in particular AGOA. The key informants on the other hand felt that due to COMESA being a regional agreement, issues of costs associated with distance fall off hence the country stands to benefit more. This also holds true for SADC, however, for COMESA the RoO are more relaxed compared to those in SADC hence making it even more beneficial.

In terms of challenges leading to the low utilization of preferences, the two surveys both pointed to NTMs which are categorized as internal or external. Among the major internal challenges faced by exporters in utilizing the preference schemes are: lack of production capacity, poor infrastructure, and poor knowledge of markets, exchange rate instability, policy inconsistencies; and high transport costs. Externally, most of the exporters attributed the low utilization to difficulties in meeting SPS measures for agro produce, TBTs, costly rules of origin and cumbersome paperwork requirements.

In terms of impact most of the exporters felt that the preference schemes had a positive impact on their firms in terms of opening new market, stimulating trade, increasing profitability and the number of employees and sales. What differed however, was the extent to which the agreements impacted on them with some firms strongly agreeing while others merely agreeing yet others being indifferent. The exporters also felt that the trade agreements had significantly contributed to the development of exports of the country in general. On the other 
hand, the key informants generally felt that there had been very little impact of the agreements on both the firms and the country as a whole. They however felt that the agreements had permitted the opening of new markets and had fostered Foreign Direct Investment (FDI) inflows.

Finally, the exporters alleged that the Government and trade associations were vital in facilitating the utilization of preferences. The respondents however felt that while Government had played an active role in facilitating the use of benefits from the trade agreements, there was need for more support from both the Government and trade associations particularly in the following areas: market access services, access to finance, technology and product development services, supply of inputs, technical assistance, infrastructure and information services, and policy and advocacy. The associations felt that actions by the government such as tax incentives on the importation of raw materials, duty drawbacks, manufacturing under bond and creation of a revolving fund with a very low interest were important actions to promote the use of the agreements and help exporters produce and export more to the international markets.

While these preferential schemes are intended to improve a country's competitiveness, bolster diversification and economic growth, propel employment and ultimately reduce poverty, they have done very little to achieve these objectives in Zambia. For instance, in terms of competitiveness, for the periods 2014 to 2017, on average the country was ranked 125 out of 137 countries while the annual average economic growth rate averaged 3.7 percent during the same period. Zambia's unemployment rate was high, averaging 7.78 percent annually between the periods 2014 to 2017. Moreover, the country's poverty levels also remained high, with 54.5 percent of the people in Zambia being poor as of 2015. Furthermore, the economy remains seemingly undiversified with exports continuing to be dominated by copper and metal products constituting about 76 percent of country's total exports as of 2017. Nontraditional exports were only 24 percent in the same year, of which the manufacturing sector accounted for 12.7 percent while the agriculture sector accounted for 8 percent. Therefore, in conclusion, if the Zambia is to reap the benefits of these preferential agreements, it need to address the internal and external challenges.

\section{Acknowledgements}

The author would like to acknowledge the valuable input of Prof. Biswajit Dhar for his valuable comments and input to this study.

\section{References}

Africa Growth and Opportunity Act (AGOA). (2014). AGOA's general Rules of Origin, 2014. Retrieved August 27, 2018 from https://agoa.info/about-agoa/rules-of-origin.html

Africa Growth and Opportunity Act (AGOA). (2014). Apparel Rules of Origin, 2014. Retrieved August 27, 2018 from https://agoa.info/about-agoa/apparel-rules-of-origin.html

Akinmade, B., Khorana, S., \& Adedoyin F. F. (2020). An Assessment of the United Kingdom's trade with Developing Countries under the Generalized System of Preferences. Journal of Public Affairs. https://doi.org/10.1002/pa.2308

Cirera, X., \& Alfieri, A. (2012). Unilateral trade preferences in the EU: An empirical assessment for the case of Mozambican Exports. Economics Research International 691302. https://doi.org/10.1155/2012/691302

Condon, N., \& Stern, M. (2011). The Effectiveness of African Growth and Opportunity Act (AGOA) in Increasing Trade from Least Developed Countries: A Systematic Review. EPPI-Centre, Social Science Research Unit, Institute of Education: University of London.

Espitia, A., Mattoo, A., Mimouni, M., Pichot, X., \& Rocha, N. (2018). How Preferential Is Preferential Trade? Policy Research Working Paper 8446. https://doi.org/10.1596/1813-9450-8446

European Commission. (2005). Generalised System of Preferences: EU GSP+ granted to an additional 15 Developing Countries. European Commission.

European Commission. (2014). Basic Rules. Brussels: European Commission.

European Union. (2001). Council Regulation 2501/2001 (2001). Brussels: European Union.

European Union. (2001). Council Regulation 416/2001 (2001). Brussels: European Union.

European Union. (2010). Council Regulation 1063/2010 (2010). Brussels: European Union.

Gil-Pareja, S., Llorca-Vivero, R., \& Martínez-Serrano, J. A. (2014). Do Nonreciprocal Preferential Trade Agreements Increase Beneficiaries' Exports? Journal of Development Economics 107, 291-304. https://doi.org/10.1016/j.jdeveco.2014.01.002 
Gil-Pareja, S., Llorca-Vivero, R., \& Martínez-Serrano, J. A. (2019). Reciprocal vs nonreciprocal trade agreements: Which have been best to promote exports? PLoS ONE, 14(2), e0210446. https://doi.org/10.1371/journal.pone.0210446

Hakobyan, S. (2015). Accounting for underutilization of trade preference programs: The US generalized system of preferences. Canadian Journal of Economics, 48(2), 408-436. https://doi.org/10.1111/caje.12131

Harris, T. J., \& Suominen, K. (2009). Business costs of the Spaghetti Bowl in Latin America: Report on the Survey of Private Sector use of PTAs in Chile, Colombia, Mexico and Panama (mimeo). http://doi.org/10.1111/caje.12131

Jones, V. C. (2017). Generalized System of Preferences: Overview and Issues for Congress. Congressional Research Service Report.

Katsuhide, T., \& Urata, S. (2010). On the use of FTAs by Japanese firms: Further evidence. Business and Politics 12(1). https://doi.org/10.2202/1469-3569.1310

Klasen, S., Martínez-Zarzoso, I., Nowak-Lehmann, F., \& Bruckner, M. (2016). Trade Preferences for Least Developed Countries. Are they Effective? Preliminary Econometric Evidence. CDP Policy Review Series. United Nations Committee for Development Policy.

Swedish National Board of Trade (NBT). (2018). The Use of the EU's Free Trade Agreements: Exporter and Importer Utilization of Preferential Tariffs. National Board of Trade Sweden.

Organisation for Economic Co-operation and Development (OECD). (2013). The impact of Regional Trade Agreements on Chilean fruit exports: Report declassified at the 69th session of the Joint Working Party on Agriculture, 24 May 2013. Organisation for Economic Co-operation and Development.

Thelle, M., Jeppesen, T., Gjodesen-Lund, C., \& van Biesebroeck, J. (2015). Assessment of Economic Benefits Generated by the EU Trade Regimes towards Developing Countries.

United Nations Conference on Trade and Development (UNCTAD). (2003). Trade Preferences for LDCs: An Early Assessment of Benefits and Possible Improvements. United Nations.

United Nations Conference on Trade and Development (UNCTAD). (2018). Non-Tariff Measures: Economic Assessment and Policy Options for Development. United Nations.

United Nations Conference on Trade and Development (UNCTAD). (2019). Economic Development in Africa Report 2019: Made in Africa, Rules of Origin for Enhanced Intra-Africa Trade. United Nations.

United States Government. (2000). Trade and Development Act of (2000). United States Government.

World Trade Organization (WTO). (2019). WTO members examine utilization of tariff preferences for LDCs, links to rules of origin. WTO Committee on Rules of Origin.

\section{Website}

http://tao.wto.org

www.dataweb.usitc.gov

\section{Appendix}

\section{Appendix 1. List of key-informants}

\begin{tabular}{llll}
\hline Label & \multicolumn{1}{c}{ Informant } & Sector & Contact person \\
\hline KI-1 & Zambia Association of Manufacturers & Association & Policy Analyst \\
KI-2 & Zambia Chamber of Commerce and Industry & Association & Chief Executive Officer \\
KI-3 & Zambia Development Agency & Government & Senior Investment Promotion Officer \\
KI-4 & Zambia Ministry of Commerce, Trade, and Industry & Government & Director-Foreign Trade \\
KI-5 & Zambia Export Growers Association & Association & Chief Executive Officer \\
\hline
\end{tabular}

\section{Copyrights}

Copyright for this article is retained by the author(s), with first publication rights granted to the journal.

This is an open-access article distributed under the terms and conditions of the Creative Commons Attribution license (http://creativecommons.org/licenses/by/4.0/). 